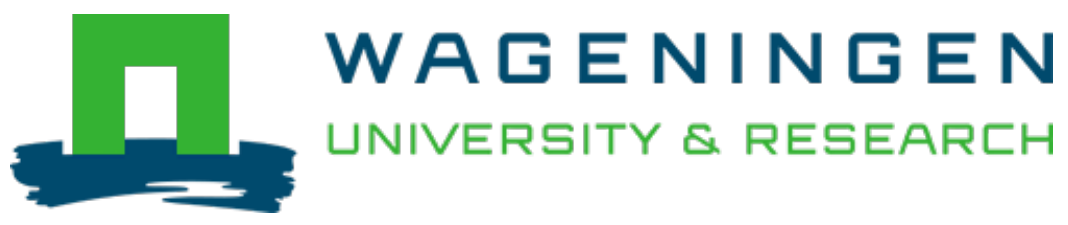

\title{
Phylogenetics of African Rinorea (Violaceae): Elucidating Infrageneric Relationships using Plastid and Nuclear DNA Sequences
}

\author{
Systematic Botany \\ Velzen, R.; Wahlert, G.A.; Sosef, M.S.M.; Onstein, R.E.; Bakker, F.T. \\ https://doi.org/10.1600/036364415X686486
}

This article is made publicly available in the institutional repository of Wageningen University and Research, under the terms of article $25 \mathrm{fa}$ of the Dutch Copyright Act, also known as the Amendment Taverne. This has been done with explicit consent by the author.

Article 25 fa states that the author of a short scientific work funded either wholly or partially by Dutch public funds is entitled to make that work publicly available for no consideration following a reasonable period of time after the work was first published, provided that clear reference is made to the source of the first publication of the work.

This publication is distributed under The Association of Universities in the Netherlands (VSNU) 'Article $25 \mathrm{fa}$ implementation' project. In this project research outputs of researchers employed by Dutch Universities that comply with the legal requirements of Article $25 \mathrm{fa}$ of the Dutch Copyright Act are distributed online and free of cost or other barriers in institutional repositories. Research outputs are distributed six months after their first online publication in the original published version and with proper attribution to the source of the original publication.

You are permitted to download and use the publication for personal purposes. All rights remain with the author(s) and / or copyright owner(s) of this work. Any use of the publication or parts of it other than authorised under article $25 \mathrm{fa}$ of the Dutch Copyright act is prohibited. Wageningen University \& Research and the author(s) of this publication shall not be held responsible or liable for any damages resulting from your (re)use of this publication.

For questions regarding the public availability of this article please contact openscience.library@,wur.nl 


\title{
Phylogenetics of African Rinorea (Violaceae): Elucidating Infrageneric Relationships using Plastid and Nuclear DNA Sequences
}

\author{
Author(s): Robin van Velzen, Gregory A. Wahlert, Marc S. M. Sosef, Renske E. Onstein, and Freek T.
} Bakker

Source: Systematic Botany, 40(1):174-184.

Published By: The American Society of Plant Taxonomists

URL: http://www.bioone.org/doi/full/10.1600/036364415X686486

BioOne (www.bioone.org) is a nonprofit, online aggregation of core research in the biological, ecological, and environmental sciences. BioOne provides a sustainable online platform for over 170 journals and books published by nonprofit societies, associations, museums, institutions, and presses.

Your use of this PDF, the BioOne Web site, and all posted and associated content indicates your acceptance of BioOne's Terms of Use, available at www.bioone.org/page/terms_of_use.

Usage of BioOne content is strictly limited to personal, educational, and non-commercial use. Commercial inquiries or rights and permissions requests should be directed to the individual publisher as copyright holder. 


\title{
Phylogenetics of African Rinorea (Violaceae): Elucidating Infrageneric Relationships Using Plastid and Nuclear DNA Sequences
}

\author{
Robin van Velzen, ${ }^{1,4,6}$ Gregory A. Wahlert, ${ }^{2}$ Marc S. M. Sosef, ${ }^{1,5}$ Renske E. Onstein, ${ }^{3}$ and Freek T. Bakker ${ }^{1}$ \\ ${ }^{1}$ Biosystematics Group, Wageningen University, Wageningen, the Netherlands. \\ ${ }^{2}$ Department of Biology, University of Utah, Salt Lake City, Utah 84112, U. S. A. \\ ${ }^{3}$ Institute of Systematic Botany, University of Zurich, Zollikerstrasse 107, Zurich 8008, Switzerland. \\ ${ }^{4}$ Naturalis Biodiversity Center (section NHN), Einsteinweg 2, 2333 CC Leiden, The Netherlands. \\ ${ }^{5}$ Botanic Garden Meise, Domein van Bouchout, Nieuwelaan 38, 1860 Meise, Belgium. \\ ${ }^{6}$ Author for correspondence (robin.vanvelzen@wur.nl)

\section{Communicating Editor: Donald H Les}

\begin{abstract}
Rinorea is a pantropical genus of shrubs and small trees within the family Violaceae. The genus is particularly diverse in Africa where species are ecologically important as they are often abundant or even dominant in particular forest types and act as larval host plants for highly specialized Cymothoe butterflies. Despite their importance, species identification of African Rinorea is difficult and a taxonomic revision is needed. Previous phylogenetic studies have suggested that neotropical taxa are sister to a palaeotropical clade, with multiple independent dispersals to Madagascar, but these were based on plastid data only. We therefore present an updated phylogeny of Rinorea with increased sampling of African taxa, using plastid as well as nuclear DNA sequences. Phylogenetic relationships inferred from nuclear DNA data were generally congruent with those based on evidence from plastid haplotypes from earlier studies. Our increased taxonomic sampling also revealed previously undiscovered African Rinorea clades, some of which warrant further taxonomic study. Ancestral state reconstructions refute previous hypotheses about the evolution of morphological characters traditionally used for Rinorea infrageneric classification. In addition, some widespread species may comprise species complexes. It is clear that African Rinorea require comprehensive taxonomic revision; our contribution to understanding Rinorea infrageneric relationships will facilitate this task.
\end{abstract}

Keywords-Biogeography, character evolution, chloroplast DNA, embryo defective 2765, Madagascar, taxonomy.

Rinorea Aubl. is a pantropical genus of shrubs and small trees, and with an estimated 280 species, it represents the second most species-rich genus in Violaceae after Viola L. (Ballard et al. 2014). Rinorea species diversity is well-documented in the Neotropics (49 species; Hekking 1988) and Madagascar (41 species; Wahlert 2010), but the numbers of species in Asia (ca. 30 species; Ballard and DeMuria, unpubl. data) and Africa are uncertain. Estimates of the total number of African species range from 110-150, making Africa by far the richest continent in terms of Rinorea species diversity (Achoundong 2000). Cameroon and Gabon are particularly species-rich (approximately 55 and 49 species, respectively; Bos 1989; Achoundong 1996; Bakker et al. 2006; Sosef et al. 2006) and appear to be regions of endemism for the genus (Achoundong 1996; Achoundong 2000; Tchouto et al. 2009), coinciding well with recognized hotspots of overall botanical diversity (Küper et al. 2004).

African Rinorea mainly occur in the understory of humid or semi-deciduous forests (Achoundong 1996), where they can be abundant or even dominant in the lower forest strata (Guillet et al. 2001; Wagner 2001; Kenfack et al. 2007; Githae et al. 2008; Djuikouo et al. 2010; Chuyong et al. 2011). Usually restricted to specific environments, African Rinorea are considered useful bioindicators for forest typification (Achoundong 1996; Achoundong 2000; Adomou et al. 2006; Mwavu and Witkowski 2009; Tchouto et al. 2009; Djuikouo et al. 2010; van Velzen and Wieringa 2014). Their habitat specificity and common local endemism has been explained by low seed dispersal abilities because Rinorea fruits are dry dehiscent capsules that contain few and relatively heavy seeds that do not appear to be zoochorous (Hekking 1988; Achoundong 1996; Achoundong 2000; Bakker et al. 2006; Tchouto et al. 2009). Local zones of high Rinorea species diversity have been hypothesized to represent refuge areas during glacial maxima, possibly reflecting their low dispersal rate since then (Sosef 1996; Achoundong 2000; Anhuf et al. 2006; Tchouto et al. 2009; Hardy et al. 2013). As various Rinorea species usually co-occur locally, they provide a case for future nichepartitioning studies (e.g. Wiens et al. 2010).

In addition, Rinorea species are ecologically significant as larval host plants for Cymothoe (Nymphalidae), a butterfly genus distributed throughout tropical Africa and Madagascar. At least 32 Cymothoe are highly specialized on particular species of Rinorea and most are monophagous (Fontaine 1982; Amiet and Achoundong 1996; McBride et al. 2009). Several closely related (or even cryptic) Cymothoe species have been found to colonize different but usually related species of Rinorea (Fontaine 1982; Amiet 1997; Amiet 2000; McBride et al. 2009; van Velzen et al. 2009) suggesting that Rinorea associations may have played a role in their diversification (McBride et al. 2009; van Velzen et al. 2013). Finally, species of Rinorea are used as traditional medicinal plants in various parts of Africa (Bouquet 1969; Bouquet 1974; Iwu 1993; Neuwinger 2000; N'guessan et al. 2011) and have been found to contain weakly antioxidant essential oils (Agnaniet et al. 2003) as well as an isoflavone, which is considered to be an agent against schistosomiasis (Stewart et al. 2000).

Despite their scientific, ecological, and medicinal importance, species identification of African Rinorea is difficult and specimens are regularly unidentified in ecological (Kenfack et al. 2007; e.g. Tchouto et al. 2009) and taxonomic studies (e.g. Robson 1960; Hawthorne and Jongkind 2006; Sosef et al. 2006). This is primarily due to an outdated taxonomic framework. The most recent comprehensive taxonomic overview of African Rinorea species was published by Brandt in 1914. He produced an infrageneric classification primarily based on characters of the androecium, which was adopted by De Wildeman (1920) and Melchior (1925). However, this classification includes some problematic groups that are "transitional" ( $R$. subsect. Lobiferae) or based on subtle differences such as the general shape of the anthers ( $R$. subsects. Kamerunenses and Brachypetalae) or "fleshiness" of the flowers 
(R. subsect. Crassiflorae), and it is therefore difficult to confidently assign species to their recognized infrageneric groups (Bos 1989; Wahlert 2010). In addition, classification is based on assumptions about character evolution that have not been tested phylogenetically. Furthermore, since the last classification numerous new species have been published (e.g. Taton 1968; Achoundong and Cheek 2003; Achoundong and Bakker 2006; van Velzen and Wieringa 2014), while others await their formal description (Achoundong 1996); these factors affirm the need for a full revision of African Rinorea. Thus, although Dowsett-Lemaire and White (1990) already stated that "Rinorea badly needs a critical pan-African revision" this objective has not yet been achieved today, rendering Rinorea an urgent case taxonomically. While a comprehensive revision is outside the scope of the present study, we contribute to a better understanding of the phylogenetic history of the genus, and therefore facilitate an improved infrageneric classification, simplifying the realization of such a revision.

Recent phylogenetic studies within the Violaceae clade inferred the genus Fusispermum Cuatrec. as the first-diverging extant lineage (Tokuoka 2008; Wurdack and Davis 2009; Wahlert et al. 2014). Rinorea diverges next, with the 'Apiculata' group (Hekking 1988; represented by R. apiculata Hekking) as sister to all other Rinorea (Tokuoka 2008). As the latter relationship received only low support, we refer instead to the wellsupported clade in that study, comprising all Rinorea but excluding the morphologically divergent 'Apiculata' group (i.e. R. apiculata, R. crenata M. Brandt, and R. oraria Steyerm. \& A. Fernández; Hekking 1988), as Rinorea s. s.

After an initial phylogenetic reconstruction of African Rinorea, which indicated the presence of two main African haplotypes and two African/Malagasy sister group relationships (Bakker et al. 2006), Wahlert and Ballard (2012) produced a more inclusive phylogenetic hypothesis for the genus based on plastid DNA sequences (99 accessions/68 taxa). They found that all Neotropical Rinorea s. s. are sister to a Palaeotropical clade, which is subdivided into two clades: species from the first clade have three ovules per ovary, those from the second clade have six ovules per ovary. Within both the three-ovule clade and the six-ovule clade, Malagasy taxa appear sister to those from mainland Africa, suggesting a total of four independent dispersals from mainland Africa to Madagascar (Bakker et al. 2006; Wahlert and Ballard 2012), although this possibility has never been tested within an absolute time-frame. Within the Palaeotropical Rinorea clade, Wahlert and Ballard (2012) found eleven African and Malagasy plastid haplotypes that appeared to be congruent with infrageneric groupings delimited in morphometric studies by Wahlert (2010), although not all haplotypes received high support.

In spite of the fact that these studies have collectively advanced our understanding of African Rinorea systematics greatly, two issues remain. First, a phylogenetic perspective based on nuclear DNA is still lacking. Because plastid markers have the same (maternally inherited) phylogenetic history, they do not permit reconstruction of actual clades instead of plastid haplotypes (Nichols 2001). Second, sampling of African taxa is still limited. For a large number of African taxa, it is yet unknown how they relate to the plastid haplotypes discovered by Wahlert and Ballard (2012). Moreover, unsampled taxa may represent additional, undiscovered clades. Therefore, in order to address these issues, we present an updated phylogeny of Rinorea with increased tax- onomic sampling, using plastid as well as nuclear DNA sequences. In particular, we address the following questions: (1) Is phylogenetic signal of nuclear DNA sequences congruent with that of those from the chloroplast? (2) Does a phylogenetic tree based on increased taxonomic and character sampling confirm the existing infrageneric classification? (3) How did morphological characters that are traditionally used for Rinorea infrageneric classification actually evolve?

\section{Materials AND Methods}

Taxon Sampling-We selected Fusispermum laxiflorum Hekking and Rinorea crenata ('Apiculata' group) as outgroup taxa, based on Tokuoka (2008), Wahlert (2010), Wahlert and Ballard (2012), and Wahlert et al. (2014). The ingroup comprised 146 accessions of 75 taxa, which included four Asian species (ca. 13\% of Asian taxa), five Neotropical species (i.e. ?10\% of Neotropical taxa; two from the informal group 'Rinorea' and three from the group 'Pubiflora'; Hekking 1988). The majority, though (128 accessions), comprised 60 African and/or Malagasy species (roughly $50 \%$ of known African taxa). Taxon sampling of African and Malagasy species represented each of the 11 infrageneric groups identified in earlier qualitative and morphometric studies of floral morphology by Wahlert (2010). Voucher information and GenBank accession numbers are given in Appendix 1.

DNA Extraction, Amplification, and Sequencing-DNA was extracted using the hot CTAB method (Doyle and Doyle 1987). We amplified the following three marker regions: $74 \mathrm{trnL}-F$ sequences were Sanger-generated following standard protocols using primers $C$ and $F$ from Taberlet et al. (1991); likewise, 116 nrDNA ITS sequences were generated using primers ITS1 + ITS4 (White et al. 1990); 79 sequences of exon 12 of the low-copy nuclear-encoded gene EMBRYO-DEFECTIVE 2765 (EMB2765) (Wurdack and Davis 2009) were generated using primers EMB2765ex12F and EMB2765ex12R and protocols by Horn et al. (2012). Newly generated sequences were deposited at GenBank; 74 tr $n L-F$ sequences (accession numbers KJ095711- KJ095784), 116 ITS sequences (accession numbers KJ144347-KJ144462), and 79 EMB2765 sequences (accession numbers KJ144268-KJ144346). Another 59 published trnL-F sequences were downloaded from GenBank and included in the analysis (Appendix 1).

Phylogenetic Analysis-Given the extensive length variation present in $t r n L-F$ and ITS, we adopted both MAFFT (Katoh and Toh 2008) and the 'phylogeny aware' progressive alignment approach implemented in PRANK (Loytynoja and Goldman 2009), as these approaches avoid subjective (i.e. manual) optimization of ensuing indels. MAFFT settings included E-INS-i strategy and gap opening costs of 1.0 ("mafft.bat-op 1-ep 0-maxiterate 1000-retree 1-genafpair-reorder input > output"). PRANK alignments were generated using webPRANK (Loytynoja and Goldman 2010) with default settings but without the use of clustalW for guide tree generation nor CHAOS alignment anchoring to increase alignment accuracy. The EMB2765 marker contained no length variation and therefore alignment was not an issue.

We analyzed each marker region separately, and trnL-F and ITS in both alignment versions (MAFFT and PRANK), amounting to a total of five unpartitioned matrices. In addition, in order to assess possible effects of missing data, we compiled four concatenated matrices (i.e. combining the marker regions; matrices ' $\mathrm{A}$ ', ' $\mathrm{B}^{\prime},{ }^{\prime} \mathrm{C}^{\prime},{ }^{\prime} \mathrm{D}$ '), varying from 149 accessions ( $27 \%$ missing data; ' $\mathrm{A}$ ') to 71 accessions (squared matrix, no missing data; 'D'), see Table 1. Each of A, B, C, and D was concatenated twice, based on either MAFFT or PRANK alignment versions, amounting to eight concatenated, and a grand total of 13 matrices to be analysed.

Maximum likelihood analyses were conducted using RAxML as implemented on the RAxML-HPC-Blackbox webserver (Stamatakis et al. 2008) on the CIPRES portal (Miller et al. 2010), setting GTR as the model of sequence evolution and a gamma distribution (with four classes) to model rate variation over sites. Clade support was assessed with rapid bootstrapping and measuring the percentage of replicates supporting that clade (bootstrap support; BS).

Bayesian inference was conducted using MrBayes 3.2.1, setting mixed models, allowing MrBayes to integrate over different GTR submodels using model jumps (nst $=$ mixed) and gamma-distributed variation of rates (with four classes) to model rate variation over sites. Analyses consisted of two independent runs of 50 million generations, each with four metropolis-coupled incrementally heated chains (temp $=0.05$ ) and sampling every 10,000th generation. Convergence of the two independent MCMC runs was assessed topologically (i.e. based on clade frequencies) using the online service AWTY (Nylander et al. 2008) and based on 
TABle 1. Data matrices and alignments. Concatenated matrices A, B, C, and D have different levels of missing data, see text. Note that all matrices except EMB2765 come in two alignment versions based on PRANK and MAFFT respectively, resulting in a total of 13 matrices. \#characters = number of unaligned characters; \#informative = number of informative sites within the alignment.

\begin{tabular}{|c|c|c|c|c|c|c|c|c|}
\hline \multirow[b]{2}{*}{ Matrix } & \multicolumn{4}{|c|}{ Number of accessions } & \multirow[b]{2}{*}{ \#characters } & \multirow[b]{2}{*}{ Version } & \multirow[b]{2}{*}{ Length } & \multirow[b]{2}{*}{ \#informative } \\
\hline & $\operatorname{trn} L-F$ & ITS & $E M B 2765$ & Total & & & & \\
\hline \multicolumn{9}{|l|}{ Un-partitioned } \\
\hline \multirow[t]{2}{*}{ trn $L-F$} & 133 & & & & 864 & MAFFT & 1,120 & 133 \\
\hline & & & & & & PRANK & 1,356 & 117 \\
\hline \multirow[t]{2}{*}{ ITS } & & 116 & & & 707 & MAFFT & 825 & 297 \\
\hline & & & & & & PRANK & 1,022 & 286 \\
\hline$E M B 2765$ & & & 79 & & 942 & n. a. & 942 & 142 \\
\hline \multicolumn{9}{|l|}{ Concatenated } \\
\hline \multirow[t]{2}{*}{ A } & 133 & 116 & 79 & 149 & 2513 & MAFFT & 2,887 & 572 \\
\hline & & & & & & PRANK & 3,320 & 545 \\
\hline B & 99 & 99 & 70 & 99 & 2513 & MAFFT & 2,887 & 494 \\
\hline $\mathrm{C}$ & 77 & 74 & 79 & 80 & 2513 & MAFFT & 2,887 & 490 \\
\hline $\mathrm{D}$ & 71 & 71 & 71 & 71 & 2513 & MAFFT & 2,887 & 460 \\
\hline
\end{tabular}

model parameters using Tracer 1.5 (Rambaut and Drummond 2009). The first 5 million generations (10\%) were discarded as burn-in before calculating a $50 \%$ majority-rule consensus based on the posterior set of trees. We considered nodes with a posterior probability (PP) of $>0.90$ as clades.

Character Evolution-We reconstructed the evolution of morphological character states that have been previously used to circumscribe infrageneric groups within African Rinorea (Brandt 1914). We treated each of these characters as categorical and distinguished among states as follows: (1) number of ovules per ovary: three, six, nine, or many (30-50); (2) inflorescence type: racemose or thyrsoid; (3) leaf arrangement: opposite or alternate; (4) staminal tube morphology: entire; irregularly lacerate or deeply dentate; deeply lobed or fused only at the base; (5) anthers: filamented or sessile.

Ancestral states were reconstructed using parsimony and likelihood optimization (under the Mk-1 model) as implemented in Mesquite ver. 2.75 (Maddison and Maddison 2011). Reconstructions were performed on the posterior set of trees from the Bayesian analysis to accommodate topological uncertainty and states were counted only for trees with a uniquely best state. All multiple sequence alignments, resulting trees, and morphological data sets have been submitted to TreeBASE (study number 15179).

\section{Results}

Our taxonomic sampling covered most of the known infrageneric variation in African Rinorea, as well as a fair representation of that known from the Neotropics, Madagascar, and Asia. For some widely distributed species, for instance Rinorea ilicifolia (Welw. ex Oliv.) Kuntze and R. angustifolia Baill., our sampling covered a broad biogeographic distribution throughout West, Central, and Southern Africa, and Madagascar.

Sequences from trnL-F and ITS were length-variable up to 864 and 707 base pairs, respectively; sequences from EMB2765 were 942 base pairs long (Table 1). Because the PRANK algorithm separated characters with uncertain homology, the ensuing alignments were longer than those based on MAFFT. Such 'thinning' of alignment also led to fewer informative sites, however (Table 1). Consequently,

TABLE 2. Phylogenetic congruence among data matrices and analyses. Posterior probabilities and maximum likelihood bootstrap support values (in percentages) for selected clades (see Figs. 1A, 1B). BI = Bayesian inference; $\mathrm{ML}=$ maximum likelihood; con. = topological conflict; $\mathrm{n}$. a. = clade not available (i.e. represented by less than 2 subclades/samples); unr. = unresolved.

\begin{tabular}{|c|c|c|c|c|c|c|c|c|c|c|c|c|c|c|c|c|c|c|}
\hline \multirow[b]{2}{*}{ clade } & \multicolumn{2}{|c|}{$\operatorname{trnL}-F$ (MAFFT) } & \multicolumn{2}{|c|}{$\operatorname{trnL}-F$ (PRANK) } & \multicolumn{2}{|c|}{ ITS (MAFFT) } & \multicolumn{2}{|c|}{ ITS (PRANK) } & \multicolumn{2}{|c|}{$E M B 2765$} & \multicolumn{2}{|c|}{ A (MAFFT) } & \multicolumn{2}{|c|}{ B (MAFFT) } & \multicolumn{2}{|c|}{$\mathrm{C}$ (MAFFT) } & \multicolumn{2}{|c|}{ D (MAFFT) } \\
\hline & $\mathrm{BI}$ & ML & $\mathrm{BI}$ & ML & $\mathrm{BI}$ & ML & $\mathrm{BI}$ & ML & $\mathrm{BI}$ & ML & $\mathrm{BI}$ & ML & $\mathrm{BI}$ & ML & $\mathrm{BI}$ & ML & $\mathrm{BI}$ & ML \\
\hline Rinorea s.s. & 100 & 100 & 100 & 100 & 93 & 82 & con. & 65 & 100 & 100 & 100 & 100 & 100 & 100 & 100 & 100 & 100 & 100 \\
\hline Neotropical & unr. & unr. & unr. & unr. & 100 & 84 & 61 & 54 & 100 & 100 & 98 & 69 & 98 & 87 & 100 & 100 & 100 & 100 \\
\hline Palaeotropical & 95 & 70 & 98 & 81 & 52 & 30 & con. & con. & 100 & 100 & 98 & 73 & 100 & 100 & 100 & 100 & 100 & 100 \\
\hline Asian $+R$. subsect. Verticillatae & 67 & 30 & unr. & 32 & 100 & 46 & 54 & con. & n. a. & n. a. & 95 & 46 & 100 & 69 & 100 & 100 & n. a. & n. a. \\
\hline African & unr. & unr. & unr. & unr. & 99 & 76 & con. & con. & 69 & 27 & 97 & 56 & 100 & 93 & 97 & 78 & 95 & 61 \\
\hline Clade A & unr. & unr. & unr. & unr. & 97 & 64 & con. & con. & 55 & unr. & 97 & 48 & 100 & 88 & 100 & 89 & 100 & 81 \\
\hline R. subsect. Dentatae s. s. & 89 & 57 & 81 & 52 & 100 & 97 & 100 & 94 & 100 & 100 & 100 & 96 & 100 & 100 & 100 & 100 & 100 & 100 \\
\hline 3 ovules per ovary & 88 & 53 & 88 & 56 & unr. & con. & unr. & con. & con. & con. & 99 & 58 & 99 & 76 & 100 & 83 & 100 & 87 \\
\hline R. sect. Ardisianthus & 100 & 85 & 100 & 98 & unr. & con. & unr. & con. & con. & con. & 91 & 68 & 100 & 100 & 73 & 68 & 100 & 99 \\
\hline R. arborea group & unr. & unr. & unr. & unr. & 100 & & & & 100 & 100 & 93 & 7 & 100 & 100 & 100 & 0 & 0 & 100 \\
\hline R. sect. Cycloglossae & con. & con. & con. & con. & 100 & 100 & 100 & 99 & 100 & 97 & 99 & 98 & 100 & 100 & 100 & 100 & 100 & 100 \\
\hline R. subsect. Choriandra & con. & con. & con. & con. & 99 & 83 & 100 & 99 & 100 & 98 & 99 & 98 & 100 & 100 & 100 & 100 & 100 & 100 \\
\hline Clade B & 94 & 56 & 55 & 52 & unr. & unr. & con. & con. & unr. & con. & 92 & 50 & 92 & 69 & 96 & 68 & 95 & 54 \\
\hline R. subsect. Subintegrifoliae & 99 & 66 & 99 & 59 & 99 & 93 & 100 & 100 & 100 & 100 & 100 & 98 & 100 & 100 & 100 & 100 & 100 & 100 \\
\hline Clade C & unr. & unr. & unr. & unr. & 94 & 62 & con. & con. & con. & con. & 99 & 79 & 100 & 89 & 100 & 91 & 100 & 85 \\
\hline R. subsect. Crassiflorae & 100 & 100 & 100 & 98 & 100 & 100 & 100 & 100 & 99 & 74 & 100 & & 100 & 100 & 100 & 100 & 100 & 100 \\
\hline Clade D & unr. & unr. & unr. & unr. & 77 & 25 & con. & con. & unr. & unr. & 93 & 41 & 78 & n. a. & 98 & 64 & 97 & 64 \\
\hline R. subsec & 94 & 68 & 93 & 65 & 100 & 69 & 100 & 97 & 100 & 100 & 100 & 91 & 100 & 100 & 100 & 100 & 100 & 100 \\
\hline a group & 99 & 86 & 99 & 88 & 100 & 99 & 100 & 99 & 70 & unr. & 100 & 99 & 100 & 100 & 100 & 100 & 100 & 100 \\
\hline R. subsect. Brachypetalae s. 1 . & unr. & unr. & unr. & unr. & 95 & 59 & 88 & 47 & unr. & 25 & 98 & 78 & 100 & 100 & 100 & 100 & 100 & 100 \\
\hline
\end{tabular}


analyses based on PRANK alignments required more CPUtime while the resulting phylogenetic trees were less resolved. Results based on the different marker regions were congruent, as were those based on the four concatenated matrices. Likewise, our maximum likelihood and Bayesian analyses were highly congruent with nearly all clades with high posterior support being present also in the maximum likelihood trees (see Table 2). Results based on the PRANK alignment of the ITS data set were the most incongruent; because results based on the MAFFT alignment of the same data set were congruent with the general pattern (see Table 2 ), we attribute this incongruence to misalignment by the PRANK algorithm. PP and BS values showed a slight decrease with increased taxon sampling in the combined analyses, an effect that was less pronounced in the Bayesian analyses (see Table 2). On the other hand, matrices with more missing data also had higher taxonomic sampling. We therefore considered the Bayesian analysis of concatenated matrix 'A' based on MAFFT alignment, with 149 accessions and 2,887 characters, to be the best (and more conservative) representation of our data. For the sake of comprehensiveness we also report BS values for the same data set, while noting that these are relatively low (but higher in data sets with lower levels of missing data; see Table 2).

Phylogenetic Results-The results from the phylogenetic analyses are presented as a majority-rule Bayesian phylogenetic tree (Figs. 1A , 1B; support values of phylogenetic relationships are reported as Bayesian inference posterior probability| maximum likelihood bootstrap percentage). The single accession from the Rinorea 'Apiculata' group ( $R$. crenata) was resolved as sister to the Rinorea s. s. clade (1.00|100), which is in turn divided into a Neotropical (0.98|69) and a Palaeotropical clade $(0.98 \mid 73)$. Within the Neotropical clade, the opposite-leaved 'Pubiflora' group (1.00|84) and alternateleaved 'Rinorea' group (0.98|76) are sisters. Within the Palaeotropical clade, opposite-leaved R. subsect. Verticillatae (Engler 1902) from Madagascar (1.00|100) is sister to the Asian species $(0.95 \mid 46)$, which together are sister to a predominantly African clade $(0.97 \mid 56)$. It is peculiar that, within this African clade, two specimens from Gabon (JW4382, JW5172; 1.00|100) are sister to the remaining species in clade A (0.97|48) in the separate marker region as well as in the combined analyses. Two separate insertions of 6 and 7 nucleotides in the trnL-F marker region are synapomorphies for this clade. Clade A consists of Rinorea subsect. Dentatae s. s. (1.00|96), clade B (0.92|50), and the three-ovule clade (0.99|58) uniting Rinorea sect. Ardisianthus, the Rinorea arborea group, $R$. sect. Cycloglossae, and $R$. subsect. Choriandra. Clade B consists of $R$. subsect. Subintegrifoliae (1.00|98), clade C (0.99|79), and clade D (0.93|41). Clade C consists of a grade of $R$. subsect. Dentatae s. 1 . and $R$. subsect. Crassiflorae (1.00|100). Clade D consists of Rinorea subsect. Ilicifoliae (1.00|91), the R. squamosa group sensu Wahlert (2010; $1.00 \mid 99)$, and $R$. subsect. Brachypetalae s. 1. (i.e. including R. kamerunensis Engl.; 0.98|78).

Character Evolution-Our ancestral state reconstructions suggested low rates of change for the scored morphological character states. Reconstructions based on parsimony and likelihood optimization were nearly congruent, except for some clades where ancestral states were estimated confidently based on parsimony but equivocal based on likelihood (see details below). Figures 2A-E show the ancestral state reconstructions based on likelihood. Most sampled taxa have six ovules per ovary and this is also the reconstructed ancestral state for the Palaeotropical clade in the majority of the posterior set of trees $(96 \%$ when reconstructed based on parsimony; $91 \%$ based on likelihood) and African clades $(97 \% \mid 97 \%)$. There are only two state changes to three ovules per ovary; one in a common ancestor of the R. arborea group, $R$. sections Ardisianthus and Cycloglossae, and $R$. subsect. Choriandra (99\%|99\%), and one in R. bengalensis (Wall.) Kuntze. Outside the Palaeotropical clade, patterns of ovule number evolution are less clear: within the Neotropical clade, the number of ovules is three ('Rinorea' group) or variable (three, six, or nine; 'Pubiflora' group); $R$. crenata has three ovules, and Fusispermum has many (30-50). The ancestral number of ovules for Rinorea s. s. is three based on parsimony $(100 \%)$ and equivocal based on likelihood (99\%).

Most inflorescences in our clade of interest are thyrsoid, and this is also the reconstructed ancestral character state for all clades except two independent changes to racemose inflorescences in the ancestor of $R$. sect. Ardisianthus (70\%|70\%), $R$. sect. Cycloglossae, and $R$. subsect. Choriandra (61\%|61\%), and of the R. squamosa group $(100 \% \mid 100 \%)$.

Leaf arrangement is primarily alternate, and this is also the reconstructed ancestral character state for all clades except two independent changes to opposite leaf arrangement in the ancestor of the 'Pubiflora' group (99\%|100\%) and in the ancestor of $R$. subsect. Verticillatae $(100 \% \mid 100 \%)$.

The reconstructed ancestral staminal tube morphology was "irregularly lacerate or deeply dentate" for Rinorea s. s. (100\% based on parsimony; likelihood reconstruction was uncertain), the Palaeotropical clade $(98 \% \mid 96 \%)$, the African clade $(97 \% \mid 97 \%)$, clade A $(99 \% \mid 96 \%)$, B $(90 \% \mid 91 \%)$, and C $(99 \% \mid 99 \%)$. From the ancestral state we reconstructed a reduction of the staminal tube into "deeply lobed or fused only at the base" in the ancestors of the Neotropical clade $(98 \% \mid 87 \%), \quad R$. sect. Cycloglossae $(99 \% \mid 98 \%)$, and clade D $(86 \% \mid 43 \%)$, including the ancestors of the $R$. squamosa group $(100 \% \mid 100 \%)$ and $R$. subsect. Ilicifoliae $(100 \% \mid 100 \%)$. We reconstructed fusion into an "entire" staminal tube in the ancestors of the three-ovule clade $(99 \% \mid 97 \%), R$. subsect. Crassiflorae (100\%|100\%), and R. subsect. Brachypetalae s. 1 . $(99 \% \mid 99 \%)$.

Most anthers in our clade of interest are filamented, and this is also the reconstructed ancestral character state for all clades except the 'Rinorea' group (98\%|98\%), R. horneri Kuntze within the Asian clade, the three-ovule clade $(80 \% \mid$ $80 \%), R$. subsect. Crassiflorae $(100 \% \mid 100 \%)$, and R. subsect. Brachypetalae s. 1. (99\%|99\%).

\section{Discussion}

Our results, based on increased taxonomic sampling and two additional nuclear markers, generally confirm previous results based on plastid sequences from Wahlert and Ballard (2012). Most of the same clades were recovered, while some others (i.e. the Rinorea arborea group, $R$. sect. Cycloglossae, and $R$. subsects. Choriandra and Subintegrifoliae) now have higher PP and BS support values. The South African endemic $R$. domatiosa A. E. van Wyk remained unresolved within the three-ovule clade but appeared related to R. sect. Ardisianthus $(0.70 \mathrm{PP})$. Given the morphological similarities between $R$. domatiosa and $R$. angustifolia (e.g. ciliate staminal tube, petals reflexed at anthesis, racemose inflorescence) we expect this relation to receive higher probabilities when more DNA sequence data become available. 


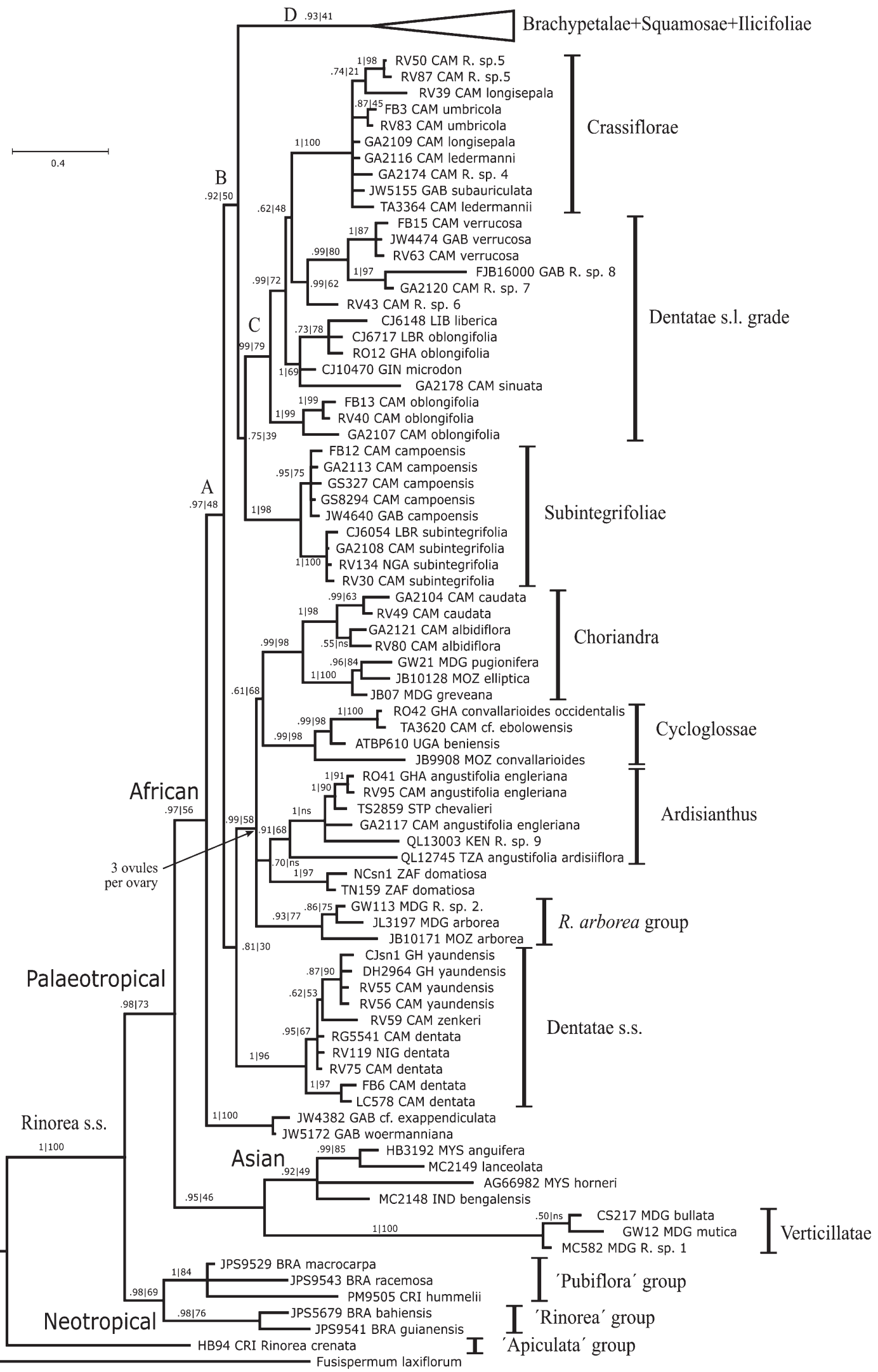

FIG. 1A Majority-rule Bayesian phylogenetic tree of Rinorea based on concatenated matrix A (see Table 1). Branch labels indicate posterior clade probabilities as well as bootstrap support percentages from maximum likelihood analysis of the same data set (ns = no support); within $R$. subsect. Ilicifoliae asterisks indicate taxa with spiny leaves; square brackets mark clades that have high support $(\mathrm{PP}=1.00)$ and are consistent with plastid haplotypes found by Wahlert and Ballard (2012); BRA = Brazil; CAM = Cameroon; CIV = Ivory Coast; $\mathrm{COM}=\mathrm{Comoros} ; \mathrm{CRI}=\mathrm{Costa}$ Rica; $\mathrm{GAB}=\mathrm{Gabon}$, GHA = Ghana; GIN = Guinea; IND = India; KEN = Kenya; LBR = Liberia; MDG = Madagascar; MOZ = Mozambique; MYS = Malaysia; NGA = Nigeria; $\mathrm{STP}=$ São Tomé and Príncipe; TZA = Tanzania; UGA = Uganda; ZAF = South Africa. 


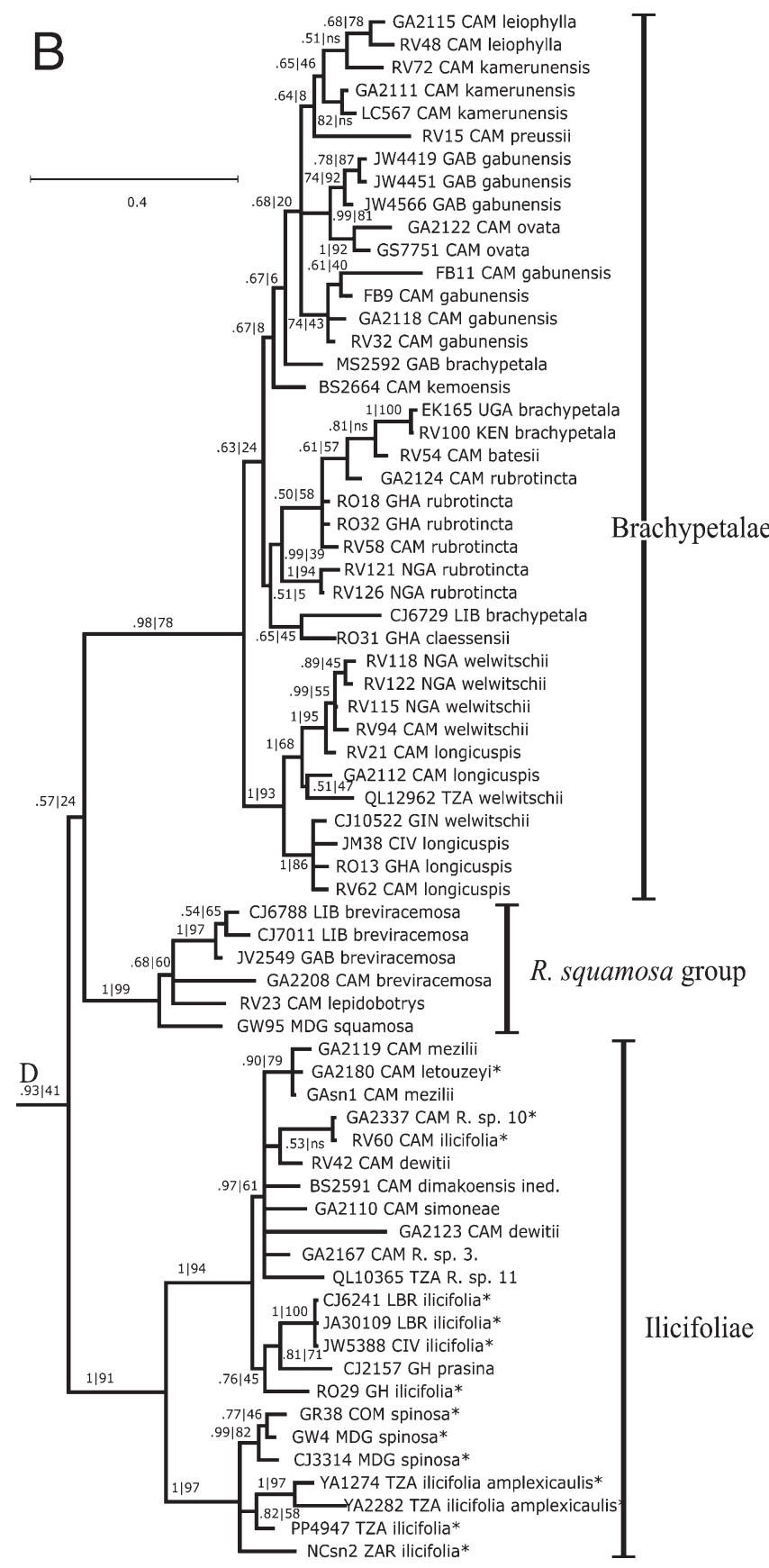

FIG. 1B. Detail of Fig. 1A, expanding Clade D.

Novel Findings-We observed several new phylogenetic patterns. First, the clade comprising Asian Rinorea and the Malagasy $R$. subsect. Verticillatae is sister to all others within the Palaeotropical clade. Consequently, the three-ovule clade is nested within the six-ovule clade rather than being its sister as suggested by Wahlert and Ballard (2012). As the ovary in Rinorea is composed of three carpels with parietal placentation of the ovules, this would imply that the ovary 'lost' one ovule per placenta (see below). Second, R. woermanniana (Buttner) Engl. and JW4382 (identified with uncertainty as $R$. exappendiculata Melch.) appear as sister to all other African species (0.97 PP $\mid 48 \%$ BS), suggesting that they require infrageneric recognition. The pistil shape of $R$. woermanniana is distinctive in having a pear-shaped ovary bearing a structurally distinct fusiform style with a protrud- ing stigma. Further study is required to determine whether this feature is a synapomorphy for the clade, however (R. exappendiculata does not have this character; specimen JW4382 only has immature fruits). Third, $R$. subsect. Dentatae appears polyphyletic. The clade comprising Rinorea dentata (P. Beauv.) Kuntze and allied species R. yaundensis Engl. and $R$. zenkeri Engl. is unresolved but may be sister to the 1-ovule clade $(0.81 \mathrm{PP} \mid 30 \% \mathrm{BP})$. Surprisingly, all other species previously classified within $R$. subsect. Dentatae (not sampled by Wahlert and Ballard 2012) are not closely related to this $R$. subsect. Dentatae s. s. clade but rather appear as a grade closely related to $R$. subsect. Crassiflorae (0.99 PP|79 BS). Finally, the African subsects. Ilicifoliae and Brachypetalae and the R. squamosa group appear to form a clade (0.93 PP $\mid 41 \% \mathrm{BS})$. Given the still limited taxonomic sampling within African Rinorea, we cannot exclude the possibility that we have missed additional clades. We therefore feel that formal taxonomic recognition of newly discovered clades would be premature.

Character Evolution-The importance of diagnostic morphological characters traditionally used to delimit infrageneric groups within African Rinorea (i.e. leaf position, number of ovules, and androecium structure; Brandt 1914), appeared to be largely confirmed by our phylogenetic tree (see Figs. 1A, 1B). However, some exceptions can be observed. For example, taxa with free stamens were traditionally classified separately from those with a staminal tube (Brandt 1914; De Wildeman 1920), and free filaments were considered primitive within Rinorea (Hekking 1988). Our results suggest that a staminal tube is a plesiomorphic character, however, and free filaments are a later reversal serving as an apomorphy within African Rinorea. Indeed, Fusispermum has connate filaments, similar to those in Palaeotropical Rinorea (Cuatrecasas 1950), corroborating that this is an ancestral rather than derived state. Our results thus confirm the hypothesis of Tokuoka (2008) that free stamens are a synapomorphy for all Violaceae except Fusispermum and Rinorea. Likewise, sections with three ovules per ovary were previously considered to be 'archaic' within African Rinorea (Achoundong 2000) but in our analyses appear to be derived. As the Malagasy $R$. subsect. Verticillatae and the Asian species have six ovules per ovary, the Palaeotropical clade probably had an ancestor with six ovules per ovary. The only other clades with three ovules are the 'Rinorea' group and the R. 'Apiculata' group, which suggests that three ovules per ovary may have been the ancestral state for Rinorea s. s. However, the Neotropical 'Pubiflora' group consists of species with three to nine ovules per ovary and Fusispermum has many ovules that give rise to two different kinds of seed (Hekking 1988; Tokuoka 2008; Ballard et al. 2014). Therefore, the ancestral number of ovules for Rinorea (and for Violaceae) could just as well be variable.

Biogeography-Although we have aimed for taxonomic sampling of all major infrageneric groups, our sampling (covering $50 \%$ of extant African species) was biased due to increased collecting efforts, especially in Cameroon. Therefore, testing historical biogeographic hypotheses within Africa or inferring evolutionary ecological trends in Rinorea requires denser sampling, especially in West and East Africa. Based on our taxonomic sampling for Neotropical (10\%) and Asian (13\%) Rinorea, theoretical hypotheses of paraphyly or polyphyly cannot be rejected for Rinorea on these continents. Nevertheless, as we included most infrageneric groups (Hekking 1988; DeMuria and Ballard, unpublished data) and all available evidence points towards monophyly of Asian and 
A
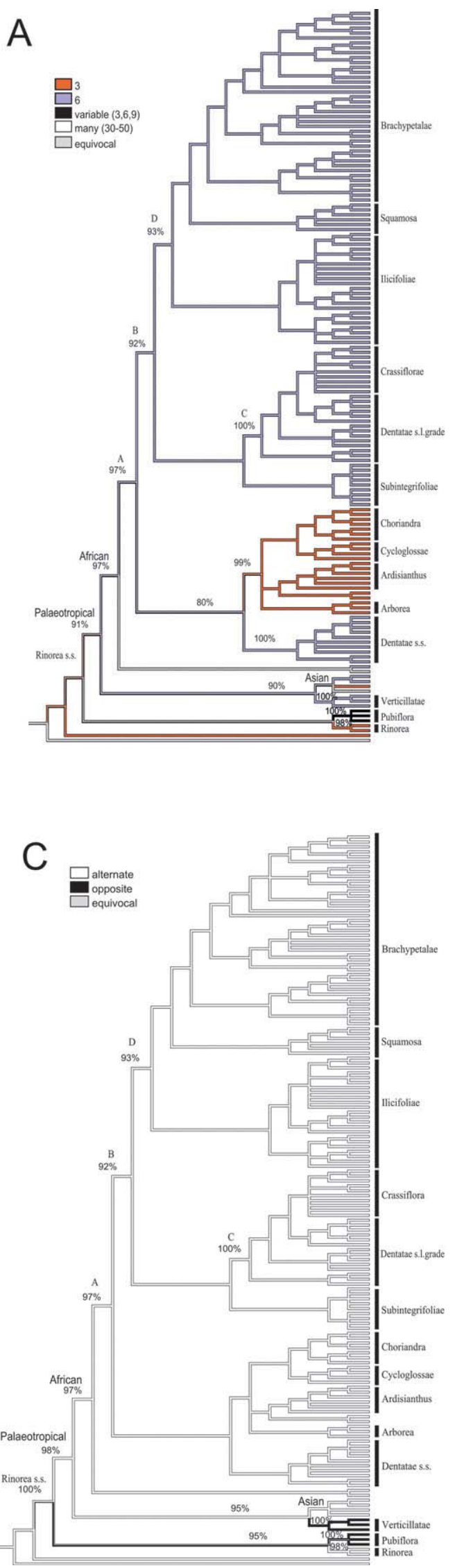
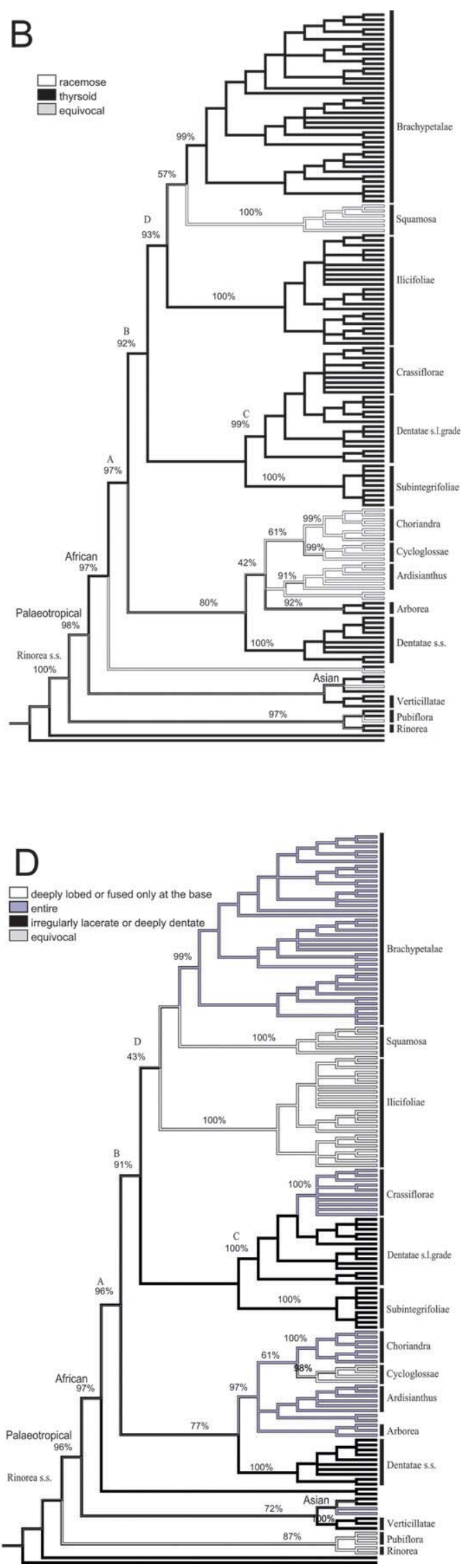

FIG. 2A-D. Ancestral state reconstructions for morphological characters using likelihood optimization. A: number of ovules per ovary; B: inflorescence type; C: leaf arrangement; D: staminal tube morphology. Ancestral states were reconstructed using parsimony and likelihood optimization (under the Mk-1 model) as implemented in Mesquite ver. 2.75 (Maddison and Maddison 2011). Node labels indicate percentage of posterior trees with a uniquely best state for that node (note that these cannot exceed the PP of that node). 


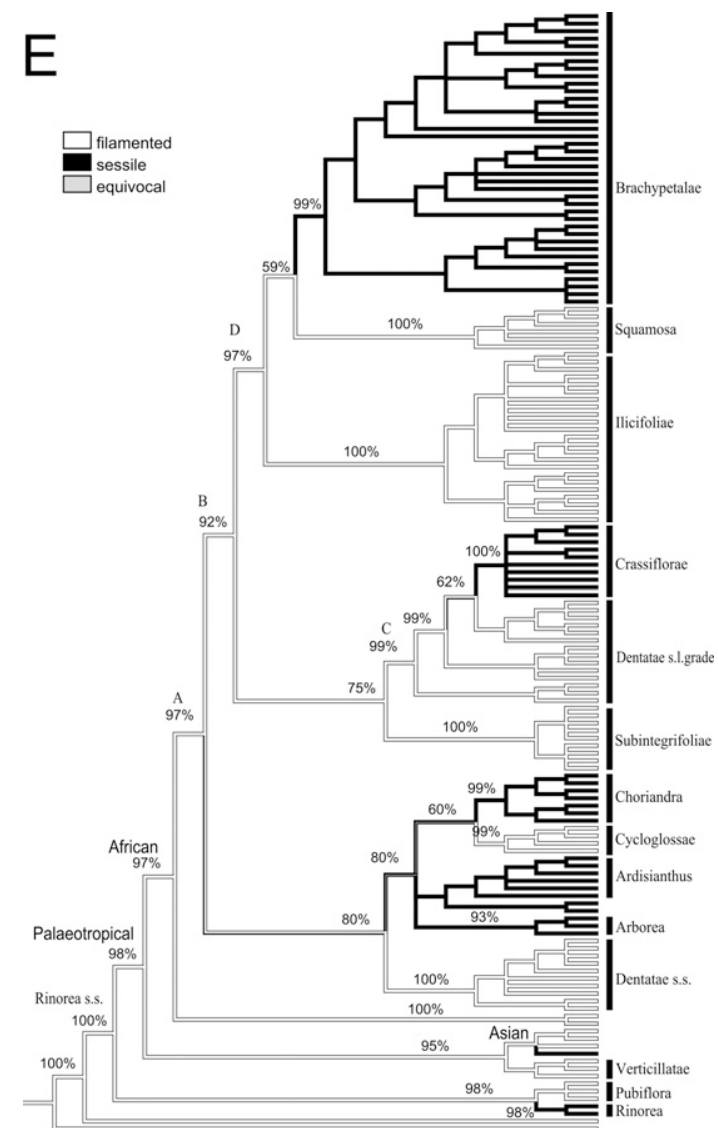

FIG. 2E. Ancestral state reconstructions for morphological characters, continued. E: Anther type.

Neotropical Rinorea s. s.. our results confirm that Madagascar was colonized five times independently; four of which come from within the African clade (i.e. the $R$. arborea group, R. subsect. Choriandra, R. squamosa, and R. spinosa (Boivin ex Tul.) Baill.).

Species-Level Patterns-Although assessing species monophyly was not a primary aim of our study, we note that some species appear to comprise non-monophyletic groups of organisms in our phylogenetic tree (Fig. 1A). Within the Rinorea subsect. Dentatae s. s. clade, two $R$. dentata specimens from southern Cameroon appear to be sister to all others, while three other specimens from Cameroon and Nigeria are more closely related to $R$. zenkeri and $R$. yaundensis. Rinorea dentata is distributed from Liberia to the Democratic Republic of the Congo (Tennant 1963; Hawthorne and Jongkind 2006) and can be variable in the field (Achoundong, pers. comm.). As one example, the flowers are cream-coloured in LC578 while they are yellow in RV119. Thus, the taxonomic status of this entity deserves closer attention and may require reinstatement of existing synonyms from southern Cameroon (i.e. R. bipindensis Engl. and R. dinklagei Engl.).

Rinorea angustifolia is a variable species distributed throughout much of tropical Africa and Madagascar (Tennant 1963; Grey-Wilson 1981). Rinorea angustifolia subsp. ardisiiflora (Welw. ex Oliv.) Grey-Wilson from Tanzania is separate from all others, while a specimen of a suspected new species from Kenya (Quentin Luke, pers. comm.) is closely related to $R$. angustifolia subsp. engleriana (De Wild. \& T. Durand) Grey-Wilson specimens from Cameroon and Ghana plus R. chevalieri Exell from Sao Tomé. Pending better sampling of this species group, the present results already show that possibly several more taxa are present and some synonyms may need to be reinstated.

Rinorea oblongifolia (C. H. Wright) Marquand ex Chipp is another variable species (Chipp 1923) currently thought to be distributed across tropical Africa (Tennant 1963; Hawthorne and Jongkind 2006). Specimens from Cameroon appear as sister to all others in the $R$. subsect. Dentatae s. 1. grade (0.99 PP| $72 \%$ BS), while those from Ghana and Liberia are closely related to $R$. sinuata Chipp, R. microdon M. Brandt, and $R$. liberica Engl. (1.00 PP $69 \%$ BS). This separation is corroborated by morphological differences (e.g. flower colour and inflorescence structure), suggesting they may represent distinct species (the type specimen is from Cameroon).

Rinorea ilicifolia is distributed throughout much of tropical Africa and is easily recognized by its distinctive spiny leaf margins (Grey-Wilson 1981). Such spiny-leaved specimens occur in at least two separate clades, however. Those from Tanzania and South Africa cluster together with $R$. spinosa from Madagascar, while those from Liberia, Ivory Coast, Ghana, and Cameroon cluster together with non-spinose species from Ghana, Cameroon, and Tanzania. Again, this inconsistency could suggest the presence of at least two taxa.

Rinorea longicuspis Engl. and R. welwitschii Kuntze appear as sisters within $R$. subsect. Brachypetalae s. 1., but three specimens (CJ10522 identified as R. welwitschii; RV21 and GA2112 identified as $R$. longicuspis) fall within the clade of its sister species. These results suggest that these specimens might be misidentified, which may mean that the most commonly used character for identification (i.e. leaf pubescence) is not reliable.

Within R. subsect. Brachypetalae s. 1., Gabonese specimens of R. gabunensis Engl. are sister to R. ovata Chipp (0.99 PP $\mid 81 \%$ $\mathrm{BS})$, while the Cameroonian specimens are separate $(0.74$ $\mathrm{PP} \mid 43 \% \mathrm{BS})$, suggesting that perhaps at least two taxa are present, although posterior probabilities are low.

These results suggest that several species that are currently regarded as widespread throughout Africa (i.e. R. angustifolia, $R$. dentata, $R$. oblongifolia, and $R$. ilicifolia) may actually comprise species complexes containing species with a more local distribution. This would then imply that African Rinorea may be even more restricted to certain environments than previously thought (Achoundong 1996; Achoundong 2000; Adomou et al. 2006; Githae et al. 2008; Mwavu and Witkowski 2009; Tchouto et al. 2009; Djuikouo et al. 2010; van Velzen and Wieringa 2014). We emphasize, however, that Rinorea species are notoriously difficult to identify and some cases of nonmonophyly could be due to misidentification. A more statistical test of species monophyly therefore requires a thorough taxonomic revision.

We present an updated phylogenetic tree of Rinorea with increased taxonomic sampling, using plastid as well as nuclear DNA sequences. Our results indicate that phylogenetic signal of the plastid and nuclear genomes are congruent. The tree largely confirms existing infrageneric classification but also reveals additional clades warranting reassessment of some taxonomic groups and perhaps the creation of new ones. Ancestral state reconstructions refute previous hypotheses about the evolution of morphological characters that are traditionally used for Rinorea infrageneric classification. In addition, some widespread species may comprise species complexes. It is clear that African Rinorea require comprehensive taxonomic revision, and we hope that our contribution 
to understanding Rinorea infrageneric relationships will prove to be helpful in realizing that task.

Acknowledgments. We are indebted to Ria Vrielink, Bram Lestrade, and Sandrina Pardoel for help in the lab. Gaston Achoundong, Olivier Sene-Belinga, Safián Szabolcsz, Stephen Davey, Andrew Walker, and Andrews Kankam Amankwah helped collect samples in the field. Editorin-chief James Smith and two anonymous reviewers made valuable suggestions for improvement of the manuscript. We thank Tinde van Andel, Lars Chatrou, Carel Jongkind, Erik Koenen, Quentin Luke, and Jan Wieringa for contributing silica samples. RvV acknowledges the Systematics Research Fund; RvV and REO acknowledge the Alberta Mennega Foundation and the Hugo de Vries Foundation for financial support; FTB acknowledges the Linnean Society of London for financial support.

\section{Literature Cited}

Achoundong, G. 1996. Les Rinorea comme indicateurs des grands types forestiers du Cameroun. Pp. 536-544 in The biodiversity of African plants, ed. L. J. G. van der Maesen, X. M. van der Burgt, and J. M. van Medenbach-de Rooy. Dordrecht: Kluwer Academic Publishers.

Achoundong, G. 2000. Les Rinorea et l'étude des refuges forestiers en Afrique. Pp. 19-29 in Dynamique à long terme des écosystèmes forestiers intertropicaux, ed. M. Servant and S. Servant-Vildary. Paris: Mémoire UNESCO.

Achoundong, G. and M. Cheek. 2003. Two new species of Rinorea (Violaceae) from western Cameroon. Kew Bulletin 58: 957-964.

Achoundong, G. and F. T. Bakker. 2006. Deux nouvelles espèces de Rinorea, série Ilicifoliae (Violaceae) du Cameroun. Adansonia 28: 129-136.

Adomou, A. C., B. Sinsin, and L. J. G. van der Maesen. 2006. Phytosociological and chorological approaches to phytogeography: A mesoscale study in Benin. Systematics and Geography of Plants 76: 155-178.

Agnaniet, H., H. Mounzeo, C. Menut, J.-M. Bessiere, and M. Criton. 2003. The essential oils of Rinorea subintegrifolia O. Ktze and Drypetes gossweileri S. Moore occurring in Gabon. Flavour and Fragrance Journal 18: $207-210$.

Amiet, J.-L. 1997. Spécialisation trophique et premières états chez les Cymothoe: Implications taxonomiques (Lepidoptera, Nymphalidae). Bulletin de la Société entomologique de France 102: 15-29.

Amiet, J.-L. 2000. Les premiers états des Cymothoe: Morphologie et intérêt phylogénique (Lepidoptera, Nymphalidae). Bulletin de la Société entomologique de France 106: 349-390.

Amiet, J.-L. and G. Achoundong. 1996. Un exemple de spécialisation trophique chez les Lépidoptères: Les Cymothoe camerounaises inféodées aux Rinorea (Violacées) (Lepidoptera, Nymphalidae). Bulletin de la Société entomologique de France 101: 449-466.

Anhuf, D., M. P. Ledru, H. Behling, F. W. da Cruz, R. C. Cordeiro, T. van der Hammen, I. Karmann, J. A. Marengo, P. E. De Oliveira, L. Pessenda, A. Siffedine, A. L. Albuquerque, and P. L. Da Silva Dias. 2006. Paleoenvironmental change in Amazonian and African rainforest during the LGM. Palaeogeography, Palaeoclimatology, Palaeoecology 239: 510-527.

Bakker, F. T., B. S. van Gemerden, and G. Achoundong. 2006. Molecular systematics of African Rinorea Aublet. (Violaceae). Pp. 33-44 in Taxonomy and ecology of African plants, their conservation and sustainable use, ed. S. A. Ghazanfar and H. J. Beentje. Richmond: Kew Publishing.

Ballard, H. E. Jr., J. de Paula-Souza, and G. A. Wahlert. 2014. Violaceae. Pp. 303-322 in The families and genera of vascular plants, vol. XI. Flowering plants. Dicotyledons: Malpighiales, ed. K. Kubitzki. Berlin: Springer-Verlag.

Bos, J. J. 1989. Clef des Violaceae ligneuses pour la partie occidentale de l'Afrique centrale. Adansonia 4: 461-468.

Bouquet, A. 1969. Féticheurs et médecines traditionnelles du Congo (Brazzaville). Paris: Mémoires ORSTOM.

Bouquet, A. 1974. Plantes médicinales de la Côte D'Ivoire. Paris: ORSTOM.

Brandt, M. 1914. Übersicht über die afrikanischen Arten der Gattung Rinorea Aubl. Botanische Jahrbücher für Systematik, Pflanzengeschichte und Pflanzengeographie 50 suppl.: 405-418.

Chipp, T. F. 1923. New species of Rinorea from West Africa. Bulletin of miscellaneous information, Royal Botanic Gardens, Kew 1923: 289-299.

Chuyong, G. B., D. Kenfack, K. E. Harms, D. W. Thomas, R. Condit, and L. S. Comita. 2011. Habitat specificity and diversity of tree species in an African wet tropical forest. Plant Ecology 212: 1363-1374.

Cuatrecasas, J. 1950. Studies in South American plants II. Fieldiana Botany 27: 55-113.
De Wildeman, E. 1920. Notes sur le genre Rinorea Aubl. Bulletin du Jardin Botanique de l'Etat à Bruxelles 6: 131-194.

Djuikouo, M. N. K., J.-L. Doucet, C. K. Nguembou, S. L. Lewis, and B. Sonké. 2010. Diversity and aboveground biomass in three tropical forest types in the Dja Biosphere Reserve, Cameroon. African Journal of Ecology 48: 1053-1063.

Dowsett-Lemaire, F. and F. White. 1990. New and noteworthy plants from the evergreen forests of Malawi. Bulletin du Jardin Botanique National de Belgique 60: 73-110.

Doyle, J. J. and J. L. Doyle. 1987. A rapid DNA isolation procedure for small quantities of fresh leaf tissue. Phytochemical Bulletin 19: $11-15$.

Engler, A. 1902. Violaceae africanae. Engler's Jahrbuch XXXIII: 132-147.

Fontaine, M. 1982. Genre Cymothoe Hübner. Lep. Nymphalidae - S. fam. Nymphalinae. Note sur les premiers états. Lambillionea 82: 63-64, 67-72, 95-98.

Githae, E. W., M. Chuah-Petiot, J. K. Mworia, and D. W. Odee. 2008. A botanical inventory and diversity assessment of Mt. Marsabit forest, a sub-humid montane forest in the arid lands of northern Kenya. African Journal of Ecology 46: 39-45.

Grey-Wilson, C. 1981. Notes on African Violaceae. Kew Bulletin 36: 103-126.

Guillet, B., G. Achoundong, J. Y. Happi, V. K. K. Beyala, J. Bonvallot, B. Riera, A. Mariotti, and D. Schwartz. 2001. Agreement between floristic and soil organic carbon isotope $(13 \mathrm{C} / 12 \mathrm{C}, 14 \mathrm{C})$ indicators of forest invasion of savannas during the last century in Cameroon. Journal of Tropical Ecology 17: 809-832.

Hardy, O. J., C. Born, K. Budde, K. Daïnou, G. Dauby, J. Duminil, E.-E. B. K. Ewédjé, C. Gomez, M. Heuertz, G. K. Koffi, A. J. Lowe, C. Micheneau, D. Ndiade-Bourobou, R. Piñeiro, and V. Poncet. 2013. Comparative phylogeography of African rain forest trees: A review of genetic signatures of vegetation history in the Guineo-Congolian region. Comptes Rendus Geoscience 345: 284-296.

Hawthorne, W. D. and C. C. H. Jongkind. 2006. Woody plants of western African forests: A guide to the forest trees, shrubs and lianes from Senegal to Ghana. Richmond: Royal Botanical Gardens Kew.

Hekking, W. H. A. 1988. Violaceae part I. Rinorea and Rinoreocarpus. New York: The New York Botanical Garden.

Horn, J. W., B. W. van Ee, J. J. Morawetz, R. Riina, V. W. Steinmann, P. E. Berry, and K. J. Wurdack. 2012. Phylogenetics and the evolution of major structural characters in the giant genus Euphorbia L. (Euphorbiaceae). Molecular Phylogenetics and Evolution 63: 305-326.

Iwu, M. M. 1993. Handbook of African medicinal plants. Boca Raton: CRC Press.

Katoh, K. and H. Toh. 2008. Recent developments in the MAFFT multiple sequence alignment program. Briefings in Bioinformatics 9: 286-298.

Kenfack, D., D. W. Thomas, G. Chuyong, and R. Condit. 2007. Rarity and abundance in a diverse African forest. Biodiversity and Conservation 16: $2045-2074$.

Küper, W., J. H. Sommer, C. L. Jon, J. Mutke, H. P. Linder, H. J. Beentje, R. S. A. R. V. Rompaey, C. Chatelain, M. Sosef, and W. Barthlott. 2004. Africa's hotspots of biodiversity redefined. Annals of the Missouri Botanical Garden 91: 525-535.

Loytynoja, A. and N. Goldman. 2009. Uniting Alignments and Trees. Science 324: 1528-1529.

Loytynoja, A. and N. Goldman. 2010. webPRANK: A phylogeny-aware multiple sequence aligner with interactive alignment browser. $B M C$ Bioinformatics 11: 579.

Maddison, W. P. and D. R. Maddison. 2011. Mesquite: a modular system for evolutionary analysis v2.75. Available from http:// mesquiteproject.org.

McBride, C. S., R. van Velzen, and T. B. Larsen. 2009. Allopatric origin of cryptic butterfly species that were discovered feeding on distinct host plants in sympatry. Molecular Ecology 18: 3639-3651.

Melchior, H. 1925. Violaceae. Pp. 359 in Die Natürlichen Pflanzenfamilien, ed. A. Engler. Leipzig: Verlag von Wilhelm Engelmann.

Miller, M. A., W. Pfeiffer, and T. Schwartz. 2010. Creating the CIPRES Science Gateway for inference of large phylogenetic trees. Gateway Computing Environments Workshop (GCE), 2010, p. 1-8.

Mwavu, E. N. and E. T. F. Witkowski. 2009. Seedling regeneration, environment and management in a semi-deciduous African tropical rain forest. Journal of Vegetation Science 20: 791-804.

N'guessan, K., D. Soro, and A. Amon. 2011. Plantes utilisées en médecine traditionnelle dans le traitement des maladies cardiovasculaires, en pays Abbey et Krobou, dans le Sud de la Côte-d'Ivoire. Phytothérapie 9: 199-208.

Neuwinger, H. D. 2000. African traditional medicine: A dictionary of plant use and applications. Stuttgart: Medpharm Scientific Publishers. 
Nichols, R. 2001. Gene trees and species trees are not the same. Trends in Ecology \& Evolution 16: 358-364.

Nylander, J. A. A., J. C. Wilgenbusch, D. L. Warren, and D. L. Swofford. 2008. AWTY (are we there yet?): A system for graphical exploration of MCMC convergence in Bayesian phylogenetics. Bioinformatics 24: $581-583$.

Rambaut, A. and A. J. Drummond. 2009. Tracer v1.5. Available from http:/ / beast.bio.ed.ac.uk/Tracer.

Robson, N. K. B. 1960. Violaceae. Flora Zambesiaca 1: 246-260.

Sosef, M. S. M. 1996. Begonias and African rain forest refuges: General aspects and recent progress. Pp. 602-611 in The biodiversity of African plants, ed. L. J. G. van der Maesen, X. M. van der Burgt, and J. M. van Medenbach-de Rooy. Dordrecht: Kluwer Academic Publishers.

Sosef, M. S. M., J. J. Wieringa, C. C. H. Jongkind, G. Achoundong, Y. Azizet Issembé, D. Bedigian, R. G. van den Berg, F. J. Breteler, M. Cheek, J. Degreef, R. B. Faden, P. Goldblatt, L. J. G. van der Maesen, L. Ngok Banak, R. Niangadouma, T. Nzabi, B. Nziengui, Z. S. Rogers, T. Stévart, J. L. C. H. van Valkenburg, G. Walters, and J. J. F. E. de Wilde. 2006. Checklist of Gabonese vascular plants. Scripta Botanica Belgica 35: 1-438.

Stamatakis, A., P. Hoover, and J. Rougemont. 2008. A Rapid Bootstrap Algorithm for the RAxML Web Servers. Systematic Biology 57: 758-771.

Stewart, M., B. Bartholomew, F. Currie, D. K. Abbiw, Z. Latif, S. D. Sarker, and R. J. Nash. 2000. Pyranoisoflavones from Rinorea welwitschii. Fitoterapia 71: 595-597.

Taberlet, P., L. Gielly, G. Pautou, and J. Bouvet. 1991. Universal primers for amplification of three non-coding regions of chloroplast DNA. Plant Molecular Biology Reporter 17: 1105-1109.

Taton, A. 1968. Rinorea nouveaux (Violaceae) de Congo-Kinshasa. Bulletin du Jardin Botanique National de Belgique 38: 381-391.

Tchouto, M. G. P., J. J. F. E. de Wilde, W. F. de Boer, L. J. G. van der Maesen, and A. M. Cleef. 2009. Bio-indicator species and Central African rain forest refuges in the Campo-Ma'an area, Cameroon. Systematics and Biodiversity 7: 21-31.

Tennant, J. R. 1963. Notes on tropical African Violaceae. Kew Bulletin 16: 409-435.

Tokuoka, T. 2008. Molecular phylogenetic analysis of Violaceae (Malpighiales) based on plastid and nuclear DNA sequences. Journal of Plant Research 121: 253-260.

van Velzen, R. and J. J. Wieringa. 2014. Rinorea calcicola (Violaceae), an endangered new species from south-eastern Gabon. Phytotaxa 167: 267-275.

van Velzen, R., T. B. Larsen, and F. T. Bakker. 2009. A new hidden species of the Cymothoe caenis-complex (Lepidoptera: Nymphalidae) from western Africa. Zootaxa 2197: 53-63.

van Velzen, R., N. Wahlberg, M. S. M. Sosef, and F. T. Bakker. 2013. Effects of changing climate on species diversification in tropical forest butterflies of the genus Cymothoe (Lepidoptera: Nymphalidae) Biological Journal of the Linnean Society 108: 546-564.

Wagner, T. 2001. Seasonal changes in the canopy arthropod fauna in Rinorea beniensis in Budongo Forest, Uganda. Plant Ecology 153: 169-178.

Wahlert, G. A. 2010. Phylogeny, biogeography, and a taxonomic revision of Rinorea (Violaceae) from Madagascar and the Comoro Islands. Ph.D. Thesis. Athens: Ohio University.

Wahlert, G. A. and H. E. Ballard, Jr. 2012. A phylogeny of Rinorea (Violaceae) inferred from plastid DNA sequences with an emphasis on the African and Malagasy species. Systematic Botany 37: 964-973.

Wahlert, G. A., T. Marcussen, J. de Paula-Souza, M. Feng, and H. E. Ballard,. 2014. A phylogeny of the Violaceae (Malpighiales) inferred from plastid DNA sequences: Implications for generic diversity and intrafamilial classification. Systematic Botany 39: 239-252.

White, T., T. Bruns, S. Lee, and J. Taylor. 1990. Amplification and direct sequencing of fungal ribosomal RNA genes for phylogenetics. Pp. 315-322 in PCR protocols: A guide to methods and applications, ed. M. Innis, D. Gelfand, J. Sninsky, and T. White. San Diego: Academic Press.

Wiens, J. J., D. D. Ackerly, A. P. Allen, B. L. Anacker, L. B. Buckley, H. V. Cornell, E. I. Damschen, T. Jonathan Davies, J.-A. Grytnes, S. P. Harrison, B. A. Hawkins, R. D. Holt, C. M. McCain, and P. R Stephens. 2010. Niche conservatism as an emerging principle in ecology and conservation biology. Ecology Letters 13: 1310-1324.

Wurdack, K. J. and C. C. Davis. 2009. Malpighiales phylogenetics: Gaining ground on one of the most recalcitrant clades in the Angiosperm tree of life. American Journal of Botany 96: 1551-1570.
Appendix 1. Voucher information and GenBank accessions in alphabetical order for sampled taxa (GenBank accessions are trnL-F, ITS, EMB2765). * indicates that the locus was not sequenced for that taxon. Herbarium acronyms follow Index Herbariorum (http://sweetgum .nybg.org/ih/).

Rinorea albidiflora Engl. CAMEROON. Njabilobe, Kribi-Ebolowa road. Achoundong 2121 (WAG) AY739723, * *; Djabilobe. van Velzen 80 (WAG) KJ095777, KJ144454, KJ144338. R. anguifera Kuntze. MALAYSIA. Ballard 3192 (WAG) AY739754, *, *. R. angustifolia Baill. subsp. ardisiiflora (Welw. ex Oliv.) Grey-Wilson. TANZANIA. Luke 12745 (WAG) KJ095740, KJ144421, KJ144310. R. angustifolia subsp. engleriana (De Wild. \& T. Durand) Grey-Wilson. CAMEROON. Douala-Edéa road. Achoundong 2117 (WAG) AY739724, KJ144376, KJ144281; Eloundem II. van Velzen 95 (WAG) KJ095781, *, *; GHANA. Kakum Forest Reserve. Onstein 41 (WAG) KJ095749, KJ144428, KJ144318. $\boldsymbol{R}$. arborea (Thouars) Baill. MADAGASCAR. Labat 3197 (MO) JN714094, * *; MOZAMBIQUE. Burrows \& Wahlert 10171 (MO) JN714095, KJ144400, KJ144296. R. bahiensis (Moricand) Kuntze. BRAZIL. Paula-Souza et al. 5679 (SPF) JN714117, KJ144402, KJ144298. $\boldsymbol{R}$. batesii Chipp. CAMEROON, Eloundem. van Velzen 54 (WAG) KJ095768, KJ144448, KJ144334. R. bengalensis (Wall.) Kuntze. INDIA. Chase 2148 (K) AY739755, *, * R. beniensis Engl. UGANDA. ATBP 610 (MO) JN714087, KJ144348, KJ144268. $\boldsymbol{R}$. brachypetala (Turcz.) Kuntze. GABON. Pélé Mountains. Sosef 2592 (WAG) KJ095738, KJ144416, KJ144308; KENYA. Yala River, Kakamega forest. van Velzen 100 (WAG) KJ095751, KJ144430, KJ144320; LIBERIA. North Lorma National Forest. Jongkind 6729 (WAG) KJ095715, KJ144358, KJ144272; UGANDA. Koenen 165 (WAG) KJ095718, KJ144363, KJ144275. R. breviracemosa Chipp. CAMEROON. Akak. Achoundong 2208 (YA) KJ095729, KJ144385, KJ144288; GABON. Doudou Mountains. van Valkenburg 2549 (WAG) KJ095731, KJ144404, *; LIBERIA. Jongkind 6788 (WAG) *, KJ144359, *; Lofa. Jongkind 7011 (WAG) KJ095716, KJ144360, *. R. bullata H. Perrier. MADAGASCAR. Skema 217 (MO) JN714069, KJ144361, KJ144273. R. campoensis M. Brandt ex Engl. CAMEROON. Bakker 12 (WAG) KJ095720, KJ144365, *; Bella SW of Edéa. Achoundong 2113 (YA) AY739725, *, *; Bipindi-Lolodorf. Shu 327 (YA) AY739745, KJ144389, *; Shu 8294 (YA) AY739742, KJ144391, *; GABON. $33 \mathrm{~km}$ on road Mbigou/Malinga. Wieringa 4640 (WAG) KJ095732, KJ144410, KJ144303. R. caudata Kuntze. CAMEROON. 5 km on EdéaDouala road. Achoundong 2104 (YA) AY739726, *, *; Ducam Duclair. van Velzen 49 (WAG) KJ095766, KJ144446, *. R. cf. ebolowensis M. Brandt. CAMEROON. Campo-Ma'an area. van Andel 3620 (WAG) KJ095783, KJ144459, KJ144342. $R$. cf. exappendiculata Melch. GABON. ferry port to Ikobey. Wieringa 4382 (WAG) AY739752, KJ144405, KJ144300. R. chevalieri 2012SAN TOME. Stévart 2859 (MO) JN714099, KJ144460, KJ144343. R. claessensii 2012GHANA. Kakum Forest Reserve. Onstein 31 (WAG) KJ095747, KJ144427, KJ144316. $R$. convallarioides subsp. convallarioides (Baker f.) Eyles. MOZAMBIQUE. Burrows 9908 (BNRH) JN714088, KJ144401, KJ144297. R. convallarioides subsp. occidentalis Grey-Wilson. GHANA. Kakum Forest Reserve. Onstein 42 (WAG) KJ095750, KJ144429, KJ144319. R. crenata M. Brandt. COSTA RICA. Ballard 94-006 (WIS) JN714119, KJ144396, KJ144293. R. dentata (P. Beauv.) Kuntze. CAMEROON. Bakker 6 (WAG) KJ095724, KJ144369, *; Chatrou 578 (WAG) KJ095737, KJ144415, KJ144307; Ndian Div.: ca. 2 km NW of Ikassa village. Gereau 5541 (MO) JN714062, *, *; Bissiang. van Velzen 75 (WAG) KJ095776, * *; NIGERIA, Ologbo Forest. van Velzen 119 (WAG) KJ095752, * KJ144321. $R$. dewitii Achound. CAMEROON. Njabilobe, KribiEbolowa road. Achoundong 2123 (YA) AY739744, *, *; Eding. van Velzen 42 (WAG) KJ095763, KJ144443, *. R. domatiosa A. E. van Wyk. SOUTH AFRICA. Crouch s. n. (n. a.) JN714098, *, KJ144309; Nowell 159 (BHO) KJ095784, * *. R. elliptica Kuntze. MOZAMBIQUE. Burrows \& Wahlert 10128 (MO) JN714084, KJ144399, KJ144295. R. gabunensis Engl. CAMEROON. Bakker 11 (WAG) KJ095719, KJ144364, *; Bakker 9 (WAG) KJ095725, KJ144370, *; Douala-Edéa road. Achoundong 2118 (YA) AY739741, KJ144377, KJ144282; Eding. van Velzen 32 (WAG) KJ095760, KJ144441, *; GABON, $5 \mathrm{~km}$ on the road Ikobey-Bakongue. Wieringa 4419 (WAG) AY739739, KJ144406, *; 10km on the road Ikobey-Bakongue. Wieringa 4451 (WAG) AY739740, KJ144407, KJ144301; 27 km on road Mimongo/ Koulamoutou. Wieringa 4566 (WAG) *, KJ144409, *. R. greveana Baill. MADAGASCAR. Bolin E Razafindraibe M07-08 (MO) JN714083, KJ144398, KJ144294. R. guianensis Aubl. BRAZIL. Paula-Souza et al. 9541 (SPF) JN714118, KJ144403, KJ144299. R. horneri Kuntze. MALAYSIA. Gentry E Lafrankie 66982 (MO) JN714081, KJ144347, * * R. hummelii Sprague. COSTA RICA, Puntarenas. Maas 9505 (WAG) KJ095739, KJ144418, *. R. ilicifolia (Welw. ex Oliv.) Kuntze. CAMEROON. Eloundem. van Velzen 60 (WAG) KJ095772, KJ144453, *; GHANA. Kakum Forest Reserve. Onstein 29 (WAG) 
KJ095746, KJ144426, KJ144315; IVORY COAST. Yapo forest. Wieringa 5388 (WAG) KJ095735, KJ144413, KJ144305; LIBERIA,. Grand Gedeh. Jongkind 6241 (WAG) KJ095713, KJ144357, *; Adam 30109 (MO) JN714034, KJ144397, *; SOUTH AFRICA. Crouch s.n. (n. a.) JN714032, KJ144417, *; TANZANIA Phillipson \& Sitoni 4947 (MO) JN714033, KJ144419, *. R. ilicifolia var. amplexicaulis Grey-Wilson. TANZANIA. Abeid 1274 (MO) JN714031, KJ144461, *; Abeid 2282 (MO) JN714030, KJ144462, *. R. kamerunensis Engl. CAMEROON, Bella SW of Edéa. Achoundong 2111 (YA) AY739729, KJ144373, KJ144278; Chatrou 567 (WAG) KJ095736, KJ144414, KJ144306; Bebambwé II. van Velzen 72 (WAG) KJ095775, ***. R. kemoensis A. Chev. CAMEROON. Sonke 2664 (YA) AY739727, KJ144350, KJ144270. R. lanceolata Kuntze. MALAYSIA. Chase 2149 (K) JN714076, * *. R. ledermannii Engl. CAMEROON, Douala-Edéa road. Achoundong 2116 (YA) AY739730, *, *; Mont Elephant. van Andel 3364 (WAG) KJ095782, KJ144458, KJ144341. R. leiophylla M. Brandt. CAMEROON. Bella SW of Edéa. Achoundong 2115 (YA) AY739736, KJ144375, KJ144280; Ducam Duclair. van Velzen 48 (WAG) KJ095765, KJ144445, KJ144332. R. lepidobotrys Mildbr. CAMEROON. Kala. van Velzen 23 (WAG) KJ095758, KJ144439, KJ144327. R. letouzeyi Achound. CAMEROON, Route Bella. Achoundong 2180 (YA) AY739734, KJ144384, *. R. liberica Engl. LIBERIA. Grand Cape Mountains near Robertsport. Jongkind 6148 (WAG) *, KJ144356, *. R. longicuspis Engl. CAMEROON. Bella SW of Edéa. Achoundong 2112 (YA) AY739731, KJ144374, KJ144279; Kala. van Velzen 21 (WAG) KJ095757, KJ144438, KJ144326; Londji II. van Velzen 62 (WAG) KJ095773, * *; GHANA. Atewa Range Forest Reserve. Onstein 13 (WAG) KJ095744, KJ144425, *; IVORY COAST. Songon-Kassembré. Munzinger E Karamoko 38 (WAG) AY739757, * *. R. longisepala Engl. CAMEROON. Bella SW of Edéa. Achoundong 2109 (YA) AY739732, * *; Eding. van Velzen 39 (WAG) KJ095761, KJ144442, KJ144329. R. macrocarpa Kuntze. BRAZIL. Paula-Souza et al. 9529 (SPF) JN714108,**. R. mezilii Achound. CAMEROON. W of Song Mbong. Achoundong 2119 (YA) AY739733, KJ144378, KJ144283; CAMEROON. Boaben. Achoundong s. n. (n. a.) AY739752, KJ144387, *. R. microdon M. Brandt. GUINEA. Jongkind 10470 (WAG) KJ095711, * *. R. mutica (Tul.) Baill. MADAGASCAR. Wahlert \& Rakotonasolo 12 (MO) JN714067, *, KJ144290. R. oblongifolia (C. H. Wright) Marquand ex Chipp. CAMEROON. Bakker 13 (WAG) KJ095721, KJ144366, KJ144276; 5 km on Eéa-Douala road. Achoundong 2107 (YA) AY739735, *, *; Eding. van Velzen 40 (WAG) KJ095762, *, KJ144330; GHANA, Atewa Range Forest Reserve. Onstein 12 (WAG) KJ095743, KJ144424, KJ144313; LIBERIA. Jongkind 6717 (WAG) KJ095714, * *. R. ovata Chipp. CAMEROON. Njabilobe, Kribi-Ebolowa road. Achoundong 2122 (YA) AY739738, KJ144379, KJ144284; BipindiLolodorf. Shu 7751 (WAG) AY739737, KJ144390, *. R. prasina Chipp. GHANA. Jongkind 2157 (WAG) *, KJ144353, *. R. preussii Engl. CAMEROON. Kala. van Velzen 15 (WAG) KJ095756, KJ144437, KJ144325. $R$. pugionifera (Oudem.) H. Perrier. MADAGASCAR. Wahlert $\mathcal{E}$ Rakotonasolo 21 (MO) JN713987, KJ144393, KJ144291. R. racemosa Kuntze. BRAZIL. Paula-Souza et al. 9543 (SPF) JN714110, * , *. R. rubrotincta Chipp. CAMEROON. Right bank of Sanaga River. Achoundong 2124 (YA) *, KJ144380, *; Eloundem. van Velzen 58 (WAG) KJ095770, KJ144451, KJ144336; GHANA. Atewa Range Forest Reserve. Onstein 18 (WAG) KJ095745, * , KJ144314; Kakum Forest Reserve. Onstein 32 (WAG) KJ095748, *, KJ144317; NIGERIA. Ologbo Forest. van Velzen 121 (WAG) KJ095753, KJ144433, KJ144322; van Velzen 126 (WAG) *, KJ144435, KJ144346.
R. simoneae Achound. CAMEROON. Bella SW of Edéa. Achoundong 2110 (YA) AY739743, KJ144372, KJ144277. R. sinuata Chipp. CAMEROON. Route Song Lbog. Achoundong 2178 (YA) AY739750, KJ144383, KJ144287. R. sp. 1 [same as $R$. sp. nov. (1) in Wahlert and Ballard (2012)]. MADAGASCAR. Callmander 582 (MO) JN714071, *, *. $R$. sp. 2 [same as R. sp. nov. (2) in Wahlert and Ballard (2012)]. MADAGASCAR. Wahlert 113 (MO) JN714093, KJ144392, KJ144289. R. sp. 3 [same as Rinorea sp. 6 in Achoundong (1996)]. CAMEROON. 10 km E of Kika village. Sonke 2591 (YA) AY739728, KJ144349, KJ144269; Nko Elone. Achoundong 2167 (YA) KJ095727, KJ144381, KJ144285. R. sp. 4 [same as Rinorea sp. 9 in Achoundong (1996)]. CAMEROON. Sole. Achoundong 2174 (YA) KJ095728, KJ144382, KJ144286. R. sp. 5 [same as Rinorea sp. 12 in Achoundong (1996)]. CAMEROON. Ducam Duclair. van Velzen 50 (WAG) KJ095767, KJ144447, KJ144333; Nkolo. van Velzen 87 (WAG) KJ095779, KJ144456, *. R. sp. 6 [same as Rinorea sp. 16 in Achoundong (1996)]. CAMEROON. Eding. van Velzen 43 (WAG) KJ095764, KJ144444, KJ144331. R. sp. 7. CAMEROON. Achoundong 2120 (YA) AY739748, ** *. R. sp. 8. GABON. Breteler 16000 (WAG) KJ095726, *, *. R. sp. 9 [near $R$. angustifolia subsp. engleriana]. KENYA. Shimba. Luke \& Luke 13003 (EA) KJ095742, KJ144423, KJ144312. R. sp. 10 [near R. ilicifolia]. CAMEROON. Sangmelina, Meyomessala. Achoundong 2337 (YA) KJ095730, KJ144386, *. R. sp. 11 [near R. keayii Brenan]. TANZANIA. Ndululu FR camp. Luke 10365 (EA) JN714035, KJ144420, *. $R$. spinosa (Boivin ex Tul.) Baill. COMOROS ISLANDS. Rouhan \& Bernier 38 (MO) JN714027, KJ144388, *; MADAGASCAR. Jongkind 3314 (WAG) AY739753, KJ144354, *; MADAGASCAR. Wahlert \& Rakotonasolo 4 (MO) JN714029, KJ144394, *. R. squamosa Baill. MADAGASCAR. Wahlert 95 (MO) JN714046, KJ144395, KJ144292. $R$. subauriculata Chipp. GABON. Upper Waka. Wieringa 5155 (WAG) KJ095733, KJ144411, *. R. subintegrifolia Kuntze. CAMEROON. $5 \mathrm{~km}$ on Edéa-Douala road. Achoundong 2108 (YA) AY739746, KJ144371, *; Malimba. van Velzen 30 (WAG) KJ095759, KJ144440, KJ144328; LIBERIA. north of Lake Piso. Jongkind 6054 (WAG) *, KJ144355, *; NIGERIA. Ologbo Forest. van Velzen 134 (WAG) KJ095755, KJ144436, KJ144324. R. umbricola Engl. CAMEROON. Bakker 3 (WAG) KJ095723, KJ144368, *; Mbongo. van Velzen 83 (WAG) KJ095778, KJ144455, KJ144339. R. verrucosa Chipp. CAMEROON. Bakker 15 (WAG) KJ095722, KJ144367, *; CAMEROON. Londji II. van Velzen 63 (WAG) KJ095774, *, *; GABON. $10 \mathrm{~km}$ on the road Ikobey-Bakongue. Wieringa 4474 (WAG) AY739749, KJ144408, KJ144302. R. welwitschii Kuntze. CAMEROON. Eloundem II. van Velzen 94 (WAG) KJ095780, KJ144457, KJ144340; GUINEA. Jongkind 10522 (WAG) KJ095712, KJ144352, KJ144271; NIGERIA. Ologbo Forest. van Velzen 115 (WAG) *, KJ144431, KJ144344; van Velzen 118 (WAG) *, KJ144432, KJ144345; van Velzen 122 (WAG) KJ095754, KJ144434, KJ144323; TANZANIA. Luke 12962 (EA) KJ095741, KJ144422, KJ144311. $R$. woermanniana (Buttner) Engl. GABON. Upper Waka. Wieringa 5172 (WAG) KJ095734, KJ144412, KJ144304. R. yaundensis Engl. CAMEROON. Eloundem. van Velzen 55 (WAG) KJ095769, KJ144449; van Velzen 56 (WAG) *, KJ144450, *; GHANA. Jongkind s. n. (n. a.), KJ095717, *, *; Harder 2964 (MO) JN714063, KJ144362, KJ144274. R. zenkeri Engl. CAMEROON. Eloundem. van Velzen 59 (WAG) KJ095771, KJ144452, KJ144337. Fusispermum laxiflorum Hekking. PANAMA. McPherson 10218 (MO) JN714121,*,* . F. minutiflorum Cuatrec. ECUADOR. Esmeraldas, San Lorenzo. Aulestia $872(\mathrm{MO}, \mathrm{QCNE}) *$, KJ144351, *. 